\title{
Cameroon's Bilateral Economic Partnership Agreement: A Microsimulation Approach
}

\author{
Rodrigue Nobosse Tchoffo ${ }^{1}$, Ibrahim Ngouhouo ${ }^{2}$ \\ ${ }^{1}$ Faculty of Economics and Management, University of Dschang; PhD candidate, Dschang, Cameroon \\ ${ }^{2}$ Faculty of Economics and Management, University of Dschang; Vice Dean in charge of Programs and of academic \\ activities, Dschang, Cameroon
}

Correspondence: Rodrigue Nobosse Tchoffo, Faculty of Economics and Management, University of Dschang; PhD candidate, Dschang, Cameroon.

Received: December 16, 2019

Accepted: January 29, $2020 \quad$ Available online: February 21, 2020

doi:10.11114/aef.v7i2.4730

URL: https://doi.org/10.11114/aef.v7i2.4730

\begin{abstract}
This article studies the impact of the bilateral economic partnership agreement between Cameroon and the European Union on microeconomic indicators including poverty and inequality. The analyses are based on a dynamic microsimulation model on which the scenario of the complete cancellation of customs tariffs on imports of the EU origin products is applied. This is based on a social accounting matrix that we have implemented for 2016 and the ECAM 4 household data survey collected in 2014. The results show that: The Cameroon's EPA on the macroeconomic aspect leads to an increase of imports against a decrease of exports and production; the increasing of imports is going through a decreasing of market price for domestic market against an increase of imported price. This leads to an elevation of the exchange rate and then discourages the imports of agricultural products; contrary, there is a decreasing of industrial price for imported products on domestic market. This break the local industries efforts since their indirect taxes are increasing. There are also GDP loses of about $0.14 \%$ per year. On the microeconomic aspect, it undermines and even exacerbates poverty reduction efforts through indicators of incidence, depth and severity of poverty. This impact increases from 2016 to 2040, period of our simulations, and is more pronounced in rural than in urban areas. For inequality, our results show that the agreement leads to an increase in inequalities ranging from 0.43 to 0.46 during the period 2016-2023. However, the impact is vanished between the period 2033-2040.
\end{abstract}

Keywords: inequality, poverty, economic partnership agreement, microsimulation model

JEL classification: C68, D58, H22, I32

\section{Introduction}

Cameroon is engaged since 2009 through its strategy document for growth and employment in a so-called emergence program by 2035. However, given the trend of many economic indicators, a doubt rapidly raised about the achievement of such an objective. For instance, the observed rate of GDP that was initially projected at $7.3 \%$ in 2015 was established to only 5.8\%. Therefore, the government has quickly taken measures to catch up with the implementation of a number of actions like the three-year strategic plan for which a budget of CFAF 1000 billion was allocated.

However, Cameroon will be the only country in the Central Africa sub region for having made the Economic Partnership Agreements applicable with the European Union in August 04, 2016. This is a response from the government following the pressure made by the UE on the ACP States in order to continue to benefit from preferential agreements initiated since the 1960s. The gradual dismantling of customs barriers to EU products, which otherwise is the main trading partner with more than $30 \%$ of Cameroon's trade raises questioning.

While on the other hand, the security climate remains conflictual, with the far north region facing the war against Boko Haram, and the north west and south west regions facing the secessionist conflict, it is clear that such an agreement, which consists of a cancellation of customs tariffs on imports of EU origin products without being the main cause, contributes significantly to the decline of the national economic tendency.

Among the work on microsimulation in Cameroon, the topics discussed are important as well as those on the EPAs issues (Emini \& Fofack, 2004; Emini et al., 2006; Minkoa \& Djiogap, 2013). For example, Emini et al. (2006) have 
investigated in three scenarios the impact of the devaluation of the CFAF, tax and customs reform, and investment in infrastructure on inequality and poverty. But none of this work has dwelt on the issue of EPAs. This vacuum partly justifies our interest in this research whose objective is to evaluate the impact of the Cameroonian EPA on poverty and inequalities essentially. Another reason is that, the work on EPAs for the most part denounces the inappropriateness of these for the ACP States. Indeed, many of these works find in these agreements an unbalanced character which leads to huge losses for the ACP countries (Elgstrom \& Larsen, 2010; Kuruk, 2012; Bernal, 2013; Weinhardt \& Moerland, 2017; Bouët et al., 2017; Carim, 2017). This justifies the argument defended by Gammage (2014) for whom EPAs are a means used by the EU to convey their standard of law and democracy in other countries. These factors therefore lead us to address the question of whether Cameroon's bilateral EPA affects the level of poverty and inequality in Cameroon.

Thus, to answer this question, Section 2 presents the review of the literature on EPAs apprehended by microsimulation; section 3 presents the evolution of some indicators of poverty and inequality in Cameroon; the methodology that guides our scientific approach is presented in section 4 followed by the main results presented in section 5 . Section 6 finally concludes.

\section{Litterature Review}

We first give an overview of the theoretical framework on the link between poverty and international trade followed by empirical aspect which summarizes studies on EPA apprehended by microsimulation.

\subsection{Theoretical Aspects of International Trade Effects on Poverty}

This theoretical framework is inspired from the work of Dodd \& Catteneo (2006) and covers only the poverty aspect.

The impact of international trade on income distribution has traditionally been analysed with reference to orthodox trade theory and in particular the Stolper-Samuelson theorem. These analyses can serve as a starting point for analyses of the link between trade and poverty. In general, the controversy surrounding the link between growth and poverty has suggested that international trade reduces poverty in the long run and that this reduction is the result of growth. Several authors have addressed this question (Frankel \& Romer, 1999; Rodriguez \& Rodrik, 1999; Dagdeviran et al., 2000; Dollar, 2001; Kiely, 2004). Even if the controversy is about the income redistribution link, there is still a consensus that trade liberalization can lead to poverty reduction if it is used to redistribute income and wealth created to the poor or, if it increases income for a large number of the poor.

\section{Stolper-Samuelson theorem}

This theorem derives from two conventional theories and each of them has a different perception of the consequences of internal redistribution of wealth created from international trade. These theories are: the orthodox theory of international trade and the new theory of international trade. Despite some flaws left by the orthodox theory, it rests on solid bases: for example, it is based on the Ricardian theory which considers that only the labour has a value and this is the only factor of production, and that all the units used are homogeneous. From there, Stolper \& Samuelson (1941) address the problem of the consequences of the distribution of trade through the price equalization factor according to the neoclassical Hecksher-Ohlin configuration. Thus, in their basic model with two factors of production (capital and labour), they assume that: a country has a comparative advantage in goods whose production is relatively intensive in the factor for which it is relatively well with.

Thus, Stolper-Samuelson's corollary states that: "Trade openness increases the real income of the country, which has an abundant factor and reduces the income of the country whose factor is scare". This theorem defends the following argument: the opening of trade to a labour-abundant country increases the relative price of the exports, which increases the capacities of exports sectors and factor demand used intensively. The result is an increase in the nominal output of labour while the capital (which is used intensively in the import sectors) is rather down. The final impact is measured by comparing this change in nominal income to the change in prices.

Thus, the neoclassical restriction shows that, in perfect competition, the prices of the factors used in the export sector increase in equal measure to the increase in the price of exported goods. Therefore, this Stolper-Samuelson theorem has presented its limits.

This is why studies such as Jones (1971) and Samuelson (1971) propose an improvement of the latter by developing a model with specific factors. They assume in the simplified version to relax the Stolper-Samuelson theory that, capital is a specific factor to the sector in which it was already installed while the labour remains mobile between sectors. This hypothesis is constantly postulated at the basis of several models developed today like the EXTER + model of Decaluwé et al. (2001). But, the link between trade liberalization and poverty is always not clear in these models as long as they recognize only two sources of income (including the exploitation of labour and labour). This is a criticism made by Winters (2000a) who argues that household poverty depends on the sector in which they are employed (depending on whether they have skilled or unskilled labour). Thus, for the mobile labour factor, the total effect of trade depends on 
consumption habits. If this labour force is owned by poor households (which would be observed among unskilled households), and where prices have increased with trade, the impact on household poverty may be severe given the high proportion of households' income spent by these households on their consumption.

Starting from the new theory of international trade, it is possible, contrary to Stolper-Samuelson's theorem, to take advantage of international trade from the exploitation of the two factors of production. However, this advantage would be of little benefit to the poorest when it assumes the existence of a variety of demand which is usually accompanied by a high level of per capita income. Households with unskilled labour will have an income below the poverty line.

\subsection{Empirical Aspect of the Studies on EPAs Apprehended by Microsimulation}

Research on EPAs captured by microsimulation is as diverse as that of the macroeconomic impact (Cororaton, 2004; Boysen \& Mathews, 2009; Bouët et al., 2013; Ayoki, 2013; Obeng, 2015; Viroleau, 2015; Cororaton, 2016; Boysen \& Mathews, 2016; Bouët et al., 2017). Among these authors, some worked in the Asian zone while others dwelt on the case of West and South Africa. But for many of these studies, it appears that the application of EPAs leads to a reduction of poverty. This is the case of Boysen and Mathews (2009) who find an impact of $-0.06 \%$ on the Ugandan economy and Cororaton (2016) which has an impact of $-1.6 \%$ in the Philippines. However, it has been found that these impacts vary according to the place of residence. This is for example the case of Cororaton (2004) and Obeng (2015) who reported that poverty decreases much faster in urban than in rural areas. Cororaton (2004) justifies this reduction in poverty by lowering consumer prices and increasing income.

As regards inequalities, the conclusions of most of these studies rather indicate a negative impact for the ACP States (Boysen \& Mathews, 2009; Bouët et al., 2013; Viroleau, 2015). Viroleau (2015) puts a particular emphasis on gender inequalities in the case of Senegal and finds that the EPA contributes to widening the wage gap between men and women.

As regards the effects of the agreement on welfare, most of the work finds a positive impact, which is in line with the customs union theory which stipulates that entry of new products leads to a decrease in price of goods on the domestic market and thereby improving household welfare.

It should be noted, however, that apart from the work of Oben (2015), most of these studies were conducted in a static setting; moreover, to our knowledge no study has yet been conducted in the case of the Bilateral Cameroon EPA that has been effective since August 04, 2016. These arguments justify our interest in this work.

\section{Change in Poverty and Inequalities in Cameroon}

There is no need to recall that poverty and inequality are long-standing phenomena. To better appreciate their behavior, Table 1 and Table 2 illustrate the evolution of poverty while Table 3 and Figure 1 reflect the evolution of inequalities in Cameroon.

Table 1 shows that the level of poverty decreased by almost 2.7 percentage points between 2001 and 2014 (from $40.2 \%$ to $37.5 \%$ ), although the poverty line has clearly improved from CFAF 74,002 to $130,275^{1}$. The number of poor has increased from 6,217,059 to 8,088,876 as shown in Table 2. Note that according to ECAM 4 in its report on trend, profile and determinants of poverty in Cameroon between 2001 and 2014, an amount of CFAF 775.3 billion is necessary for this purpose to bring the poorest out of poverty. This amount represents approximately $23.4 \%$ of the government budget for 2014 .

As for Table 3 on inequality, the income gap between rich and poor remains problematic. The GINI index rose from 0.40 to 0.44 between 2001 and $2014^{2}$. However, the phenomenon is much more pronounced in urban than in rural areas. This reflects the gap between the poorest $20 \%$ and the richest $20 \%$ as shown in the Figure 1 on household consumption.

Table 1. Evolution of monetary poverty index

\begin{tabular}{lll}
\hline year & poverty threshold & poverty index \\
\hline $\mathbf{2 0 0 1}$ & 74002 & $40.2 \%$ \\
\hline $\mathbf{2 0 0 7}$ & 83161 & $39.9 \%$ \\
\hline $\mathbf{2 0 1 4}$ & 130275 & $37.5 \%$ \\
\hline
\end{tabular}

Source: ECAM 4 (trend, profile and determinants of poverty in Cameroon between 2001 and 2014)

\footnotetext{
${ }^{1}$ However, this change is not glaring with regard to the pathway in the GESP, which predicted a poverty rate of below $35.2 \%$ in 2015 and $28.7 \%$ in 2020 (see GESP, Table 48, page 164, Appendix)

${ }^{2}$ A value close to 0 indicates the weakness of inequalities while the inequalities are more pronounced for a value close
} to 1 
Table 2. Trend of monetary poverty indicators from 2001 to 2014

\begin{tabular}{|c|c|c|c|c|c|c|c|c|c|}
\hline & 2001 & & & 2007 & & & 2014 & & \\
\hline & Urban & Rural & Total & Urban & Rural & Total & Urban & Rural & Total \\
\hline Incidence (\%) & 17.9 & 52.1 & 40.2 & 12.2 & 55.0 & 39.9 & 8.9 & 56.8 & 37.5 \\
\hline depth (\%) & 4.3 & 17.3 & 12.8 & 2.8 & 17.5 & 12.3 & 1.8 & 22.9 & 14.4 \\
\hline Severity (\%) & 1.6 & 7.7 & 5.6 & 1.0 & 7.2 & 5.0 & 0.6 & 11.7 & 7.2 \\
\hline$\%$ of population & 34.8 & 65.2 & 100.0 & 35.3 & 64.7 & 100.0 & 40.3 & 59.7 & 100.0 \\
\hline$\%$ of poors & 15.5 & 84.5 & 100.0 & 10.8 & 89.2 & 100.0 & 9.6 & 90.4 & 100.0 \\
\hline Number of poors & 962415 & $\begin{array}{ll}5 & 254 \\
644 & \end{array}$ & $\begin{array}{l}6 \quad 217 \\
059\end{array}$ & 768339 & $\begin{array}{lr}6 & 362 \\
562 & \\
\end{array}$ & $\begin{array}{ll}7 & 130 \\
901 & \end{array}$ & 778748 & $\begin{array}{ll}7 & 310 \\
128 & \end{array}$ & 8088876 \\
\hline
\end{tabular}

Sources: ECAM 2, 3, et 4, INS, 2001, 2007, 2014

Table 3. Evolution of inequality index by area of residence between 2001 and 2014 (\%)

\begin{tabular}{|c|c|c|c|c|c|c|c|c|c|}
\hline & \multicolumn{3}{|l|}{2001} & \multicolumn{3}{|l|}{2007} & \multicolumn{3}{|l|}{2014} \\
\hline & Urban & Rural & Total & Urban & Rural & Total & Urban & Rural & Total \\
\hline Gini & 40.7 & 33.1 & 40.4 & 35.2 & 32.2 & 39.0 & 36.5 & 39.5 & 44.0 \\
\hline Theil (0) & 27.9 & 17.82 & 27.5 & 20.6 & 16.7 & 24.8 & 22.0 & 26.1 & 33.6 \\
\hline Theil (1) & 35.4 & 19.4 & 33.8 & 22.9 & 18.8 & 27.9 & 24.4 & 28.0 & 34.9 \\
\hline Poorest $20 \%$ con & 6.5 & 7.8 & 6.2 & 7.3 & 8.4 & 6.5 & 7.0 & 6.0 & 4.7 \\
\hline Richest $20 \%$ con & 48.4 & 42.3 & 48.7 & 43.9 & 41.8 & 47.0 & 45.1 & 47.3 & 50.6 \\
\hline
\end{tabular}

Sources: ECAM 2, 3, et 4, NIS, 2001, 2007, 2014

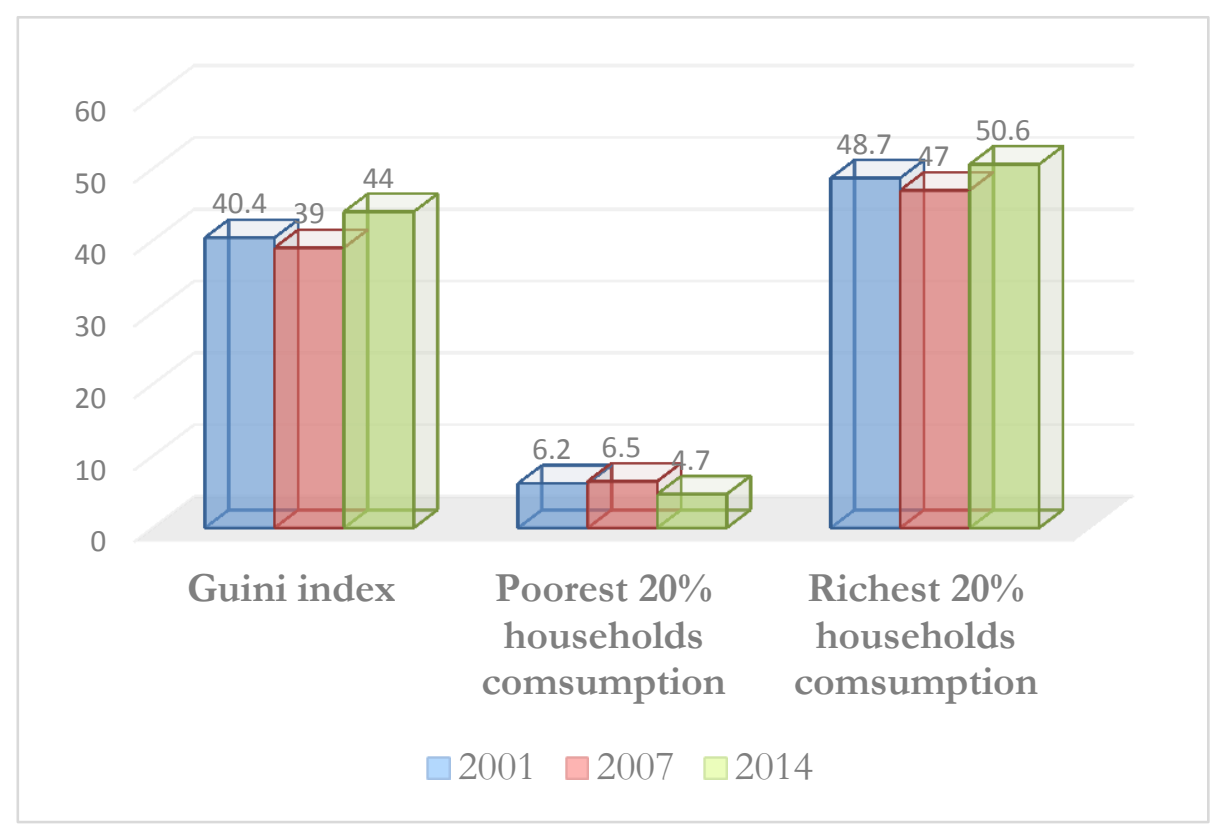

Figure 1. Evolution of inequalities index (\%). Source: authors from ECAM 4 report

Through the 2014 poverty line established to CFAF 339,715 per adult equivalent per year, or CFAF 28,310 per month and thus CFAF 931 per day, which represents the minimum amount necessary to meet the basic needs of the individual, ECAM 4 (2016) indicates that a worker in 2014 just earned the guaranteed minimum wage (SMIG) of CFAF 36,270 per month, living alone and who does not benefit from any additional income in kind (self-consumption of farm produce, housing as owner, etc.) would meet his basic needs. Since he has to support an extra adult in his household, he becomes poor.

Among the reasons given for poverty, the level of education is in perfect harmony with the evolution of poverty. Thus, the unschooled are the poorest one with a poverty rate of $66.2 \%$ followed by primary with $40.9 \%$. Lower secondary education completes the list with $22.7 \%$ compared to $13.9 \%$ for upper secondary school, while it is only $3.3 \%$ for higher education. The finding that emerges from these Figures is guided by the rate of $40.9 \%$ observed at the primary level that best reflects the current rate of $37.5 \%$ of national poverty. In order to provide more explanations on these issues, the adopted methodology is developed throughout a microsimulation model (MS) detailed below. 


\section{Methodology}

This study aims to assess the potential effects of the Cameroon-EU bilateral economic partnership agreement on poverty, as well as on inequalities. To achieve this objective, a sequential dynamic microsimulation model in line with the work of Cockburn (2001) on the integrated approach is used for our analyses.

The temporal dimension depends on the purpose of the analysis ${ }^{3}$. For example, it well carries out the analysis on income tax reform (Bourguignon \& Spadaro, 2006) or reforms of pension system or analysis of the poverty effects of macroeconomic crises (Spadaro, 2007). The short-run effects will consequently be less appreciated than the long-run effects (Bourguignon \& Spadaro, 2006). Microsimulation models are by definition quantitative. They are different from other types of analysis because their construction necessitates microeconomic data (Brown et al., 2004). Thus, we adopt the Top-Down approach developed by Bourguignon (2003b) and summarised by Hérault (2007) to move from the CGE model to the microsimulation model. In this respect, it is possible to simulate income behaviour for each of the 10,303 households in ECAM 4 data base.

\subsection{Implementation of the Model}

In order to achieve the objective mentioned above, we need to construct a computable general equilibrium model that establishes the macroeconomic interactions within the economy. Then, removing the representative agent hypothesis allows us to carry out the analyses of poverty and inequality in a microsimulation context.

\subsubsection{Description of the Model}

Cameroon is considered as a small economy, that is, it cannot influence the world prices. For the implementation of the computable general equilibrium (CGE) model, we rely on a Social Accounting Matrix (SAM) that we built for 2016. The latter is based essentially on the data collected from the 2016's Resource and Employment Table (RET) and the national data accounts. This aggregated matrix has 17 accounts: two production factor accounts; four branch accounts; four product accounts; four agent accounts including one for salaried households, one for capitalist households, one for firms, one for the government, and one account for the rest of the world; it also has one account for the customs tariff, and one accumulation account. Concerning the customs tariff account, we operate a distinction between the tariff revenue from the UE and the recorded one from the rest of the world. This is explained in the following section.

The interactions between the various sectors and economic agents are illustrated in Figure 2 below:

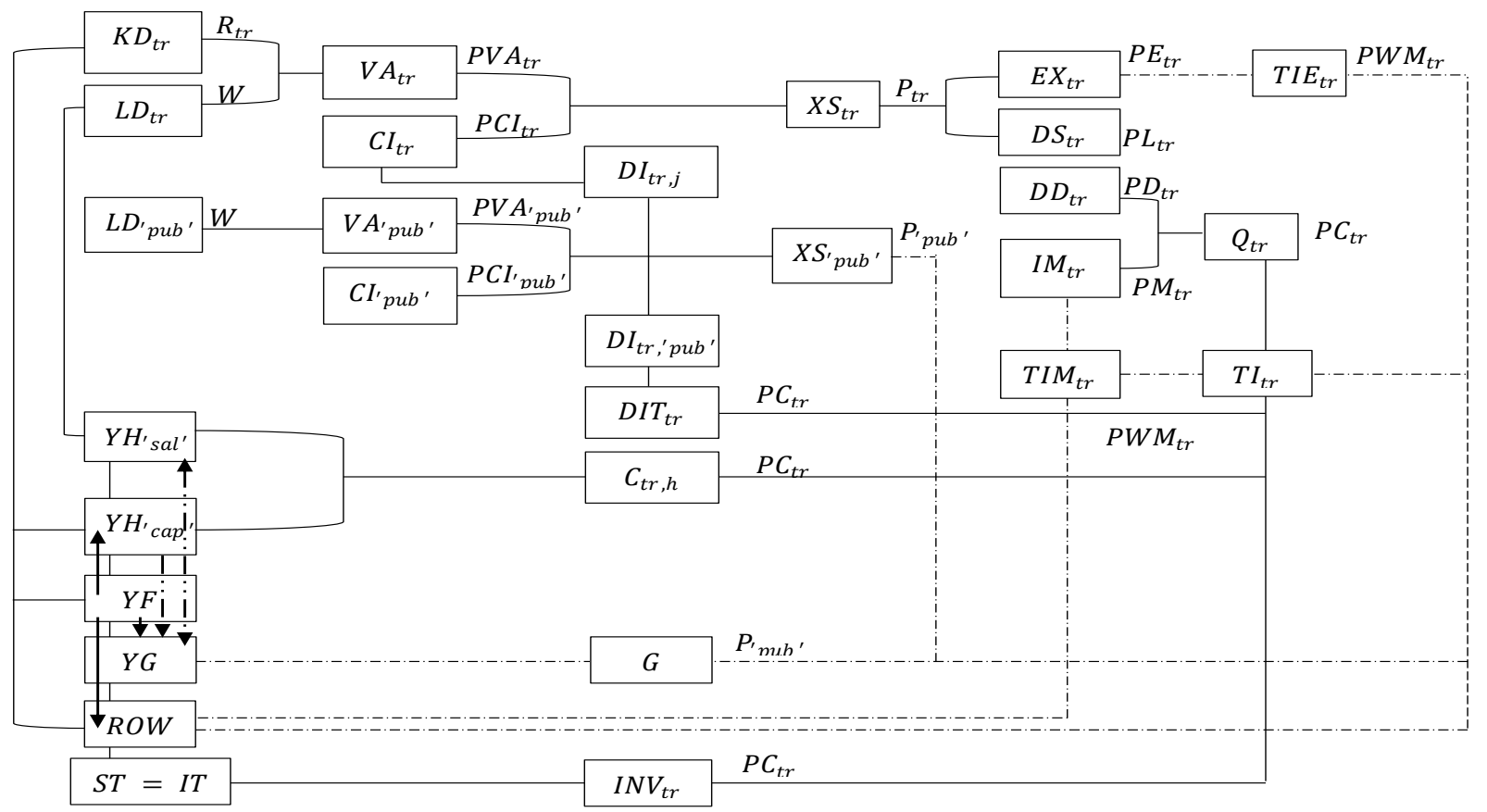

Figure 2. Model's shame representation. Source: Partnership for Economic Policy (PEP)

\footnotetext{
${ }^{3}$ Dynamics can be taken into account directly at the macroeconomic level using an inter-temporal or augmented CGE for forecasts
} 
In Figure 2 above, the total output is determined by a Leontief function between the total value added and the intermediate consumption for each branch. All products from the branches are sold on the market and the factors of production are modelled by a CES production function between capital and labour. To minimise their production costs, producers seek to determine the optimal quantities of factors needed to meet demand. Capital is supposed to be fixed while labour is mobile between branches. The mobility of the latter lets it defining the quantity of labour to be employed and the level of wage applied on the labour market. The price of the output and the world price of the exported products are fixed. The domestic price is made up of the producer price and the indirect tax on products. The price of a composite good is a function of the domestic price and the domestic market price of the imported good in each activity sector. The price of output is influenced by the price of the inputs used and in turn affects the export price. The output produced is an aggregate output. A part of the latter is sold on the domestic market and the other exported. This creates an imperfect transformation of the aggregate output for exports and domestic goods given by a constant elasticity of transformation function (CET). Producers also seek to maximize profits from their sales under transformation constraints. Export demand is assumed to be infinitely elastic. The price received by producers is expressed in local currency. The domestic market goods are sold to households, the government, and also used as intermediate inputs as well as for investment purposes. Domestic prices are flexible and reflect the balance between supply and demand of different goods in the market. Foreign supply is assumed to be perfectly elastic in relation to world prices.

Households offer the factors of production and receive in return wage remuneration for salaried households and a capital return for capitalist households. They also receive transfer income from the government, firms, other households and the rest of the world. They spend their income to purchase goods on the market, make transfers to other households, pay taxes, and then make savings.

Firms receive capital income, as well as transfers from other institutional units. They pay taxes, pay dividends to capitalist households, and make savings.

The government receives taxes. Either direct taxes collected on the households' and firms' income, or indirect taxes collected on products from different branches, or customs taxes on imports and exports of products. Its expenses consist mainly of wage remuneration for civil servants and other State agents, investments in infrastructure, transfers to households, subsidies to producers, etc. She also makes savings. Finally, the current account deficit is assumed to be fixed to limit the influence of foreign flows on the economy.

Trade liberalization policy channels'

Before presenting the different channels of trade liberalization, let's mention that the major parts of our equations are derived from Partnership for Economic Policy web page.

Impact on the import price

Let's note that the influence of trade liberalization merits to be pointed out in more than one direction: for example, we can be concerned about whether the abundance of EU origin products leads to lower prices for those on the domestic market, or if it contributes to an improvement of the households' welfare as indicated by the theory of the customs union. To better appreciate this, let's start from the following price equation:

$$
P M_{t r}=P W M_{t r} \cdot E \cdot\left(1+T X_{t r}\right) \cdot\left(1+T M_{t r}\right)
$$

The import price $\left(P M_{t r}\right)$ of product $(t r)$ is an increasing function of the customs duties $\left(T M_{t r}\right)$ and the indirect tax rate $\left(T X_{t r}\right)$ supported to enter in the local market. This price is also an increasing function of the world price $\left(P W M_{t r}\right)$ of the exported product $(t r)$ and the exchange rate $(E)$. This evolution will result from the tariff behaviour towards the EU, described by the following equation (2):

$$
T I M U E_{t r}=M_{t r} * T M_{t r} * T M U E_{t r} * P W M_{t r}
$$

Where $T_{I M U E}$ rr represents the amount of revenue from the import of EU origin products. $M_{t r}$, the total amount of imports made by the country, $T M_{t r}$, the customs duty rate applied to all imported products whatever their origin, and $T M U E_{t r}$, the fraction of the tariff revenue allocated to the EU. The latter, in 2016 is 0.311 according to Eurostat (2017).

Thus, we break down the income tariff according to two sources: one part from the EU (TMUE $\left.E_{t r}\right)$ and the other from the rest of the world $\left(T M W_{t r}\right)$ whose equation is similarly described by: 


$$
T I M W_{t r}=M_{t r} * T M_{t r} * T M W_{t r} * P W M_{t r}
$$

Equations (2) and (3) impose an equilibrium equation illustrated by:

$$
T I M_{t r}=T I M U E_{t r}+T I M W_{t r}
$$

Equation (4) shows that a cancellation of the external tariff on products from the EU reduces the amount of the total import tax to that of the rest of the world. This results in lower import price $P M_{t r}$ described in equation (1). Since this tax is a source of government revenue, the latter is reduced as described by equation (5) below through TIM $_{t r}$ :

$$
Y G=\sum_{t r}\left(T I_{t r}+T I M_{t r}+T I E_{t r}\right)+\sum_{h} T D_{h}+T D E
$$

The behaviour of the domestic price of product $t r,\left(P D_{t r}\right)$ depends on the price of products sold on the internal market $P l_{t r}$ and the indirect tax rate $\left(T X_{t r}\right)$ described by the equation (6) below. Thus, when the government will be facing difficulties to absorb the losses revenue, one could witness an increase in the indirect tax rate $T X_{t r}$ or the application of austerity measures, either by reducing wages or by increasing direct taxes.

$$
P D_{t r}=P l_{t r}\left(1+T X_{t r}\right)
$$

The production behaviour in value for which one part is intended to be sold on the domestic market and the other on the world market is implementing by equation (7) as follows:

$$
P_{t r} \cdot X S_{t r}=P L_{t r} \cdot D_{t r}+P E_{t r} . E X_{t r}
$$

Where $D_{t r}$ is the quantity to be sold on the local market and $E X_{t r}$, the quantity to be exported; $P_{t r}$, the price of the output of the $t r$ branch; $P E_{t r}$, the export price of the product $t r$. Through this mechanism, an increase in production ceteris paribus, leads to an increase in the quantity exported. As for imports, they are supposed to increase the dismantling of customs barriers leading to an increase in imports. The behaviour of the latter is captured from a CES function in relation with the Harmington hypothesis by equation (8) as follows:

$$
\frac{M_{t r}}{D_{t r}}=\left[\left(\frac{P D_{t r}}{P M_{t r}}\right) \cdot\left(\frac{1-\beta_{t r}^{M}}{\beta_{t r}^{M}}\right)\right]^{\sigma_{t r}^{M}}
$$

The well-being aspect is adopted from Decaluwé et al. (2001) using the equivalent variation approach described by equation (9) below:

$$
E V_{h}=Y M_{h} \cdot \prod_{t r}\left[\frac{P_{t r}}{P L_{t r}}\right]^{\beta_{t r}^{h}}-Y M o_{h}
$$

Where $Y M_{h}$ is the nominal household's income $h$ at the current period, and $Y M o_{h}$ its basic value; $\beta_{t r}^{h}$, the share of the product $t r$ in the total consumption of the household $h$ in value. It expresses the consumer's income gain which allows him to maintain the indirect utility level devoted to the basic period. Hence, $E V_{h}>0$ indicates an improvement of well-being while the deterioration of well-being is observed for $E V_{h}<0$.

\subsection{Calibration of the Model}

Simulation operation within a computable general equilibrium (CGE) model suppose that at the top-down, the social accounting matrix has been well-balanced. But, beyond this requirement, some intrinsic values to the model must be 
defined. These are the parameters ${ }^{4}$. However, given the complexity of the model, the values of some parameters are not available ${ }^{5}$. The calibration process meets this requirement ${ }^{6}$. As explained by Emini et al. (2006), we start from a CGE model that is assumed to be linear:

$$
Y=f(X, \beta, \gamma)
$$

Where $Y$ is the vector of the endogenous variables; $X$, the vector of the exogenous variables, $\beta$ and $\gamma$, the vectors of the parameters ${ }^{7} . \beta$ are the known parameters. Their values can come from three sources: either by econometric estimations or by adaptation when they are drawn from other countries or through the literature. In this study, we rely on the last two approaches to define the unknown parameters of our model.

It is also in this context that a sensitivity analysis of the results based on the modification of a value of these has to be conducted. On the other hand, the values of the parameters $\gamma$ remain unknown. Researching the latter values such that the basic data of the social accounting matrix (SAM) are replicated constitutes the calibration process.

Since the values of $\beta$ and endogenous and exogenous variables are known (which we note respectively by $Y_{0}$ and $X_{0}$ as values at the basic period ' 0 ') the equation (10) can be rewritten as follows:

$$
Y_{0}=f\left(X_{0}, \beta, \gamma\right)
$$

Solving equation (11), we obtain the values of parameters $\gamma$.

$$
\gamma=g\left(Y_{0}, X_{0}, \beta\right)
$$

According to equation (12), we can obtain the parameter values such as the technical coefficients of the Cobb Douglas functions or the elasticities in our model

\subsection{Closure Model}

The closure model is done around 18 variables: the EU imports' tax $\left(T I M U E_{t r}\right)$, the price $\left(P_{j}\right)$ of the output of the branch $(j)$, the world price of the product tr exported $\left(P W E_{t r}\right)$, the $(T E W)$, exports' tax, the current balance of payments deficit $(S R)$, the proceeds from the export tax of the product $t r$.

With $j=\{A G R, I N D, S E R V, S A D\}$

$\operatorname{tr} \subset j=\{A G R, I N D, S E R V\}$

\subsection{Data Survey and Their Conciliation with the SAM}

Generally, preliminary processing of household data survey is required before reconciling with the baseline SAM. In this study, we use data from Cameroon household survey (ECAM 4) conducted in 2014. This data base contains 10,303 households with 5,464 from the urban areas against 4,839 in rural areas. For the treatment purpose, Fofana \& Cockburn (2003) explain how to solve the problem of negative income declared by some households in the survey, if any, and how to adjust the income, which is generally underestimated by the households surveyed in relation to their expenses. However, in ECAM 4, no household reported a negative income, which certainly facilitates data processing. On the other hand, we adopt the technique of deflation of income and household expenditures as explained by Fofana and

\footnotetext{
${ }^{4}$ These are values that do not change during simulations

${ }^{5}$ Some suggest using the literature to determine these parameters (Shoven, 1988; Decaluwé et al., 2001) others advise to estimate them using econometric methods (Omgba \& Djiofack, 2014) for example and others propose to calibrate them directly in the model (Hosoe et al., 2010)

${ }^{6}$ Calibrate is to determine the values of the unknown parameters of the model by setting values to the endogenous variables that allow the equilibrium of the social accounting matrix (Hosoe et al., 2010)

${ }^{7}$ The $\gamma$ are called calibrated parameters while the $\beta$ are the strategic parameters or free parameters (Emini et al., 2006)
} 
Cockburn (2003) to treat negative savings in our database. Furthermore, we have to convert the data from 2014 to 2016, which is the reference year.

After this, we will adopt the top-down approach developed by Bourguignon (2003b) to move from the CGE model to the microsimulation model. The insertion of the households' income and expenditure vectors in the SAM inevitably leads to an imbalance of the latter. According to Fofana (2007), two methods are generally used to rebalance the new SAM: the imputation method and the programming method. The imputation method that we use in this study consists of distributing the income and expenditure vectors of the representative household categories of the primary matrix (capitalist households and salaried households) according to the distributive shares determined from the data. The latter are determined with respect to the different categories of households. As described by Fofana (2007), distributive shares are determined by:

$$
\beta_{h, i}^{e m}=Y_{h, i}^{e m} / \sum_{h} Y_{h, i}^{e m}
$$

With $\beta_{h, i}^{e m}$, the distributive share of income or expenditure $i$ of the household $h$ surveyed; $Y_{h, i}^{e m}$, the income or expenditure $i$ of the household $h$ and where $\mathrm{em}$ represents the household surveyed.

From $\beta_{h, i}^{e m}$, we deduce the incomes and savings $Y_{h, i}^{m c s}$ of the SAM by:

$$
Y_{h, i}^{m c s}=\beta_{h, i}^{e m} \times Y_{i}^{m c s}
$$

Where $Y_{i}^{m c s}$ is the aggregate value of the income or expenditure item of the primary SAM.

Our analyses rely on the study of Annabi et al. (2006) on dynamic microsimulation in Senegal.

\subsection{Poverty and Inequality}

The poverty analysis is commonly based on the FGT index developed by Foster et al. (1984). Concerning the inequalities, the Gini index and the Lorenz concentration curve are usually used ${ }^{8}$.

\subsubsection{Inequality}

The Gini index of the order $\alpha(\alpha>0)$ of $X$ in a population $P$ is a fraction $I_{G}^{(\alpha)}$ monotone of $\alpha$ defined by:

$$
I_{G}^{(\alpha)}(X)=\frac{1}{2 n^{2} \mu^{\alpha}} \sum_{i=1}^{n} \sum_{j=1}^{n}\left|x_{i}-x_{j}\right|^{\alpha}
$$

The value of the Gini index of the order $\alpha(\alpha>0)$ of $X$ in the subpopulation $P_{h}$ is given by:

$$
I_{G}^{(\alpha)}\left(X_{h}\right)=\frac{1}{2 n_{h}{ }^{2} \mu_{h}{ }^{\alpha}} \sum_{i=1}^{n_{h}} \sum_{j=1}^{n_{h}}\left|x_{h i}-x_{h j}\right|^{\alpha}
$$

The values of $I_{G}^{(\alpha)}$ entirely dependent on those of $X$ (Chameni, 2005). If $x_{i}=x_{j}$, then $I_{G}^{(\alpha)}(X)=0$ and the distribution is equalitarian. On the contrary, if the $i$ 's group of individuals takes all the resources in exclusion of the $j$ 's group, then the distribution will be unequal. In that case the degree of inequality is measure by:

$$
I_{G}^{(\alpha)}(X)=\left(\frac{n-1}{n}\right) \cdot n^{\alpha-1}
$$

The latter is strictly an increasing function of $\alpha$ and is greater than 1 for $\alpha>1$ and $n \geq 10$. Chameni (2005) demonstrated that for $\alpha=2$, the Gini index is twice the Herfindahl index, which is another measure of inequality.

\subsubsection{Poverty}

The poverty analysis is done through the Foster-Greer-Thorbecke (FGT) index. It focuses on the incidence of poverty

\footnotetext{
${ }^{8}$ Other indexes such as the Theil index and the Herfindahl index are often used
} 
$P_{0}$, the poverty gap $P_{1}$, and the severity of poverty $P_{2}$ (Fambon, 2017). These different indices are calculated from the following FGT function:

$$
P_{\alpha}=\frac{1}{n} \sum_{i=1}^{q}\left[\frac{z-y_{i}}{z}\right]^{\alpha}
$$

Where $n$ is the total population, $q$ the population above the poverty line, $y_{i}$ the income per individual $i, z$ the poverty line, and $\alpha$ the parameter of poverty aversion. The values of $\alpha=0,1,2$ lead to $P_{0}, P_{1}$, et $P_{2}$ respectively.

However, it is always interesting to invest in knowing the real contribution of the external shock. For that reason, Datt \& Ravallion (1992) provided a poverty decomposition into two sources: the growth component and the redistribution component. Thus, the evolution of poverty between the dates $t$ and $t+n$ is decomposable as follows:

$$
P_{t+n}-P_{t}=G(t, t+n ; r)+D(t, t+n ; r)+R(t, t+n ; r)
$$

The growth and redistribution components are expressed respectively by:

$$
\begin{aligned}
& G(t, t+n ; r)=P\left(z / \mu_{t+n}, L_{r}\right)-P\left(z / \mu_{t}, L_{r}\right) \\
& D(t, t+n ; r)=P\left(z / \mu_{t}, L_{t+n}\right)-P\left(z / \mu_{t}, L_{r}\right)
\end{aligned}
$$

For $r=t$, the residual term is expressed by:

$$
\begin{aligned}
R(t, t+n ; r) & =G(t, t+n ; t+n)-G(t, t+n ; t) \\
& =D(t, t+n ; t+n)-D(t, t+n ; t)
\end{aligned}
$$

The latter is the difference between the growth and redistribution components shown by Lorenz's initial and final curves.

Finally, it should be noted that the implementation of the recursive dynamic in this study assumes that, apart from GDP which grows at an average annual rate of $4.5 \%$, the rest of the endogenous variables of the model follow the evolution of the population growth established to $2.8 \%$ according to MINFI (2008).

\subsection{Sensitivity Analysis}

The robustness analysis of the results is done on the most sensitive parameters according to the objective of the study. Hosoe et al. (2010) put forward their importance at two levels: first, because it allows to test the robustness of the simulation results, and also because it allows to give a confidence interval on the simulation results. The authors also show the relevance of the choice of the target parameter. For example, when the study is about trade, CES and CET elasticities are good parameters because they best reflect Harmington's hypothesis. For this reason, we operate in this study a $10 \%$ drop in the elasticity of transformation.

\section{Results and Interpretations}

We first present the results of the macroeconomic analysis of the EPA before returning to those on microsimulation.

\subsection{Macroeconomic Results}

Sectoral impacts are must concerned in this section. For simplification, we have summarized those results overs three forecast subperiods from 2016 to 2040: the first period goes from 2016 to 2023, which is the period of the complete dismantling of customs barriers to $80 \%$ of products from the EU, the second period goes from 2024 to 2032; and the third one goes from 2033 to 2040 . Let's start by observing from the onset that, the import price of goods on the domestic market increases for agricultural products by $21.95 \%, 19.70 \%$ and $17.47 \%$ over the three periods respectively while industrial goods prices shift down by $12.06 \%, 36.60 \%$ and $80.94 \%$ respectively (see Table 8 ). The same observation is made for market services.

To understand what is happening, Table 7 shows that the falling market price of agricultural products $(-1.45 \%,-4.59 \%$, and $-6.08 \%$ respectively) makes the original foreign products more expensive. This situation leads to a rise in the 
exchange rate of $1.29 \%, 1.84 \%$ and $1.76 \%$ respectively (see Table 11 ), and discourages ultimately their importation into the Cameroonian market. On the other hand, the rise in market price for both industrial products and services reflects the incentive for foreign products to enter the Cameroonian market. This can explain why the Cameroonian government has been motivated by this agreement especially for importing machinery that will serve to implement a real local industry. In addition, the local producer price is rising almost for the three sectors as shown in Table 8, whereas there is a drop in the indirect tax on products excluding industrial products, whose impact is rather positive (see Table 9). These combined effects justify the declining in the market price noted previously. If we can understand this situation, we must nevertheless observe that the rise in industrial sector prices reflects the slight increase in composite demand for this sector as shown in Table 9, between 2016 and 2023.

This demand behaviour for both final and intermediate products is mainly declining (see Table 6). It shows that the EPA creates a blocking in these different sectors, which leads to a diversion effect of households for imported goods as shown in Table 5. In fact, they increase considerably for the agricultural and service sectors while production in these sectors is declining and even affecting the industry (see Table 4). This behaviour is mainly linked to value added, which is also falling steadily. The intermediate consumption of the branches does not therefore contribute strongly to this result. And this is only a logical consequence of the declining in intermediate demand of branches illustrated above. On the export side, they are also shifting down in all sectors and logically reflect the weakness of production.

Regarding the loss of customs revenue, it mainly affects the agricultural and services sectors. Table 10 shows that they decline continuously from $-1.31 \%$ to $-2.67 \%$ between 2016 and 2040 for the agricultural sector and from $-0.02 \%$ to $-0.58 \%$ for the services sector. Their decline reflects the upward trend of imports as noted above. Moreover, the monitoring and implementation committee of the bilateral Cameroonian EPA indicated in its balance sheet that losses estimated at more than CFAF 685 million were recorded one year after the implementation of the agreement in August 2016. These losses that constituted an earning from 233 economic operators, had not however experienced a real redistribution effect in the economic sphere.

In terms of macroeconomic aggregates, Table 11 shows that GDP is falling by $-0.07 \%$ between 2016 and 2023; at $-0.14 \%$ between 2024 and 2032; then to $-0.22 \%$ between 2033 and 2040. This decline is dependent on a decrease as mentioned above of the value added of the branches, and also indirect taxes collected on the products. This suggests that the agreement may hinder the growth efforts undertaken by the government if no action is taken to avoid this. There is also a gradual decline in the consumer price index after an increase in the first period. This decline also reflects the improvement in the well-being of salaried and capitalist households as shown in Table 14. This shows that the EPA has positive effects on the consumer, which is theoretically valid.

Table 4. Impact on production and value added for branches (value in \%)

\begin{tabular}{cllllll}
\hline \multirow{2}{*}{ Branches } & Production & \multicolumn{5}{c}{ Value added } \\
\cline { 2 - 7 } & $2016-2023$ & $2024-2032$ & $2033-2040$ & $2016-2023$ & $2024-2032$ & $2033-2040$ \\
\hline Agriculture & -0.89 & -2.16 & -3.12 & -0.79 & -1.83 & -2.65 \\
Industry & -0.44 & -0.98 & -1.40 & -0.38 & -0.93 & -1.31 \\
Services & 0.01 & 0.01 & -0.03 & -0.01 & 0.00 & -0.05 \\
Public serv & 0.26 & 0.58 & 0.88 & 0.27 & 0.74 & 0.98 \\
\hline
\end{tabular}

Source: Authors from GAMS software

Table 5. Impact on imports and exports (value in \%)

\begin{tabular}{lllllll}
\hline \multirow{2}{*}{ Branches } & Imports & \multicolumn{5}{c}{ Exports } \\
\cline { 2 - 7 } & $2016-2023$ & $2024-2032$ & $2033-2040$ & $2016-2023$ & $2024-2032$ & $2033-2040$ \\
\hline Agriculture & 0.91 & 2.21 & 2.78 & -0.65 & -1.19 & -1.73 \\
Industry & -0.24 & -0.51 & -0.61 & -0.24 & -0.77 & -0.98 \\
Services & 1.72 & 9.18 & 16.20 & -0.62 & -0.69 & -0.65 \\
\hline
\end{tabular}

Source: Authors from GAMS software

Table 6. Impact on domestic demand and total intermediate demand branches (value in \%)

\begin{tabular}{lllllll}
\hline \multirow{2}{*}{ Branches } & \multicolumn{2}{l}{ Demand for product tr } & \multicolumn{5}{c}{ Intermediate demand for branches } \\
\cline { 2 - 7 } & $2016-2023$ & $2024-2032$ & $2033-2040$ & $2016-2023$ & $2024-2032$ & $2033-2040$ \\
\hline Agriculture & -1.02 & -2.64 & -3.80 & -0.66 & -1.29 & -2.07 \\
Industry & -0.28 & -0.59 & -0.97 & -0.38 & -0.68 & -0.77 \\
Services & -0.11 & -0.25 & -0.43 & -0.19 & -1.04 & -0.86 \\
\hline
\end{tabular}

Source: Authors from GAMS software 
Table 7. Impact on the market price (value in \%).

\begin{tabular}{lllllll}
\hline \multirow{2}{*}{ Branches } & \multicolumn{2}{l}{ Market price of product tr } & \multicolumn{4}{l}{ Price paid for tr product exported } \\
\cline { 2 - 7 } & $2016-2023$ & $2024-2032$ & $2033-2040$ & $2016-2023$ & $2024-2032$ & $2033-2040$ \\
\hline Agriculture & -1.45 & -4.59 & -6.08 & -16.24 & -17.53 & -14.73 \\
Industry & -1.46 & 24.28 & 40.70 & 1.70 & -1.16 & -2.87 \\
Services & -0.11 & 0.13 & 0.14 & 7.01 & 0.48 & -1.23 \\
\hline
\end{tabular}

Source: Authors from GAMS software

Table 8. Impact on the producer price for its internal market selling and internal market price of imported products (value in \%)

\begin{tabular}{lllllll}
\hline \multirow{2}{*}{ Branches } & \multicolumn{2}{l}{ Producer price for its internal market selling } & \multicolumn{3}{l}{ Internal market price of imported products } \\
\cline { 2 - 7 } & $2016-2023$ & $2024-2032$ & $2033-2040$ & $2016-2023$ & $2024-2032$ & $2033-2040$ \\
\hline Agriculture & 0.08 & 0.15 & 0.01 & 21.95 & 19.70 & 17.47 \\
Industry & 1.07 & 1.08 & 0.10 & -12.06 & -36.60 & -80.94 \\
Services & 0.01 & -0.30 & -0.46 & -2997.00 & -6959.45 & -10513.65 \\
\hline
\end{tabular}

Source: Authors from GAMS software

Table 9. Impact on the composite demand for product tr and government indirect revenue (value in \%)

\begin{tabular}{lllllll}
\hline \multirow{2}{*}{ Branches } & \multicolumn{3}{c}{ Composite demand for product tr } & \multicolumn{3}{c}{ Government indirect revenue } \\
\cline { 2 - 7 } & $2016-2023$ & $2024-2032$ & $2033-2040$ & $2016-2023$ & $2024-2032$ & $2033-2040$ \\
\hline Agriculture & -0.04 & -0.04 & -0.04 & -2.32 & -6.52 & -10.23 \\
Industry & 0.02 & 0.00 & -0.02 & 0.68 & 1.75 & 2.70 \\
Services & 0.00 & -0.01 & -0.01 & -0.02 & -0.16 & -0.38 \\
\hline
\end{tabular}

Source: Authors from GAMS software

Table 10. Impact on customs revenue (value in \%)

\begin{tabular}{lllllll}
\hline \multirow{2}{*}{ Branches } & \multicolumn{2}{l}{ Customs revenue on UE imports } & \multicolumn{3}{c}{ Customs revenue on the rest of the world imports } \\
\cline { 2 - 7 } & $2016-2023$ & $2024-2032$ & $2033-2040$ & $2016-2023$ & $2024-2032$ & $2033-2040$ \\
\hline Agriculture & -1.31 & -1.83 & -2.67 & 0.37 & 0.26 & -0.71 \\
Industry & -1.00 & -1.87 & -2.45 & -0.42 & -1.30 & -1.88 \\
Services & -0.02 & -0.43 & -0.58 & 0.43 & 0.39 & 0.55 \\
\hline
\end{tabular}

Source: Authors from GAMS software

Table 11. Impact on aggregated indicators

\begin{tabular}{llll}
\hline Variables & $2016-2023$ & $2024-2032$ & $2033-2040$ \\
\hline GDP & -0.07 & -0.14 & -0.22 \\
Exchange rate & 1.29 & 1.84 & 1.76 \\
Price consumption index & 1.23 & -4.44 & -15.38 \\
Public savings & 0.00 & 0.00 & 0.00 \\
Firms' savings & -0.56 & -1.53 & -2.29 \\
Firms tax & -0.04 & -0.13 & -0.19 \\
Wage rate & 0.00 & 0.00 & 0.00 \\
Firms' revenue & -0.05 & -0.13 & -0.19 \\
\hline
\end{tabular}

Source: Authors from GAMS software

\subsection{Results of the Microsimulation Model}

First of all, it should be noted that our CGE model is part of a dynamic framework and is therefore a significant contribution in the context of microsimulation. Indeed, Annabi et al. (2008) already stressed the importance of dealing with the temporal issue in microsimulation models (MS) because static MS do not offer the opportunity to know the long-run impacts of economic policies on poverty and inequality. These authors show as Datt \& Ravallion (19912) that changes in poverty rates can be broken down into growth effects and redistributive effects in order to know whether or not trade liberalization favours the poor. However, it appears that the integration of households in the CGE model increases its size. This is not without consequence on the resolution of the equations of the model. Our simulated model using the GAMS software, included a total of 82,522 equations and 82,537 variables including 15 exogenous variables. 


\subsubsection{Impact on Poverty and Inequality Indicators}

Poverty and inequality analyses are done using the DAD software and rely solely on the FGT indices for poverty and GINI for inequality.

Starting from a national poverty line of CFAF 33,9715.3 according to ECAM 4, our analyses, which also rely on the disposable income of the households surveyed, assumes a calibration of this one over the period 2016-2040 at the rate of average annual population growth of $2.8 \%$ according to the MINFI (2008). Summing up our results for three subperiods as mentioned above, the poverty line finally retained for the first period resulting from a simple arithmetic mean is CFAF 471,367. That of the second period is CFAF 576,224.18, and that of the third period of CFAF $684,820.30$. It should also be noted that we adopted the top-down approach developed by Bourguignon (1999b) to reconcile survey data with that of the social accounting matrix. For this purpose, the imputation method as proposed by Fofana \& Cockburn (2008) allowed us to determine the distribution coefficients required for conciliation.

The following Table 12 summarizes the results found at the national level, in urban and rural areas, according to the three subperiods 2016-2023, 2024-2032 and 2033-2040 using the indexes of Foster et al. (1984). The incidence of poverty is measured by the FGT0 index, the depth of poverty measured by FGT1 and the severity of poverty measured by FGT2.

The application of the bilateral Cameroon-European union EPA under the scenario of the complete cancellation of customs tariffs with regard to products originating from the EU gives rise to a first analysis of a worsening of poverty whether at nationally or at the residential level.

At the national level, Table 12 shows that the agreement would increase the poverty rate from $36.35 \%$ to $39.73 \%$ (FGT0), which represents an increase of 3.38 percentage points in the first period. In relation to Table 13, which presents the results of the dynamic decomposition of poverty change according to Datt \& Ravallion (1992) as growth, redistribution and residual effects, we note that these 3.38 points of worsening of the EPA is due both to growth losses as mentioned above in the macroeconomic framework, and to the weakness or even decline in the redistribution of wealth created. The residual effect is quite marginal whatever the reference period chosen, but we also note that these results are quite robust because the decomposition values do not change significantly when the reference period is 1 or 2 . Indeed, the growth and redistribution effects are respectively $1.54 \%$ and $1.65 \%$ for the initial period, against $1.43 \%$ and $1.54 \%$ for the final period. It means concretely if we retain the initial period that, the growth losses decried above will contribute to increase the incidence of poverty by 1.54 percentage points as well as the redistribution which will contribute to increase it by $1.65 \%$. This amplifies the inequalities, as shown by the Gini index, which goes from 0.4319 to 0.4694 . During the period 2034-2040 the total effect of 2.08 percentage points due to the EPA is exclusively and completely due to growth losses. The rate thus goes from $32.33 \%$ to $34.80 \%$

On the other hand, the impact of the EPA would be positively perceived during the period 2024-2032 with regard to the contribution of the growth component to poverty of $-2.65 \%$, but it is advisable to be cautious to affirm because the residual component is strongly dominant. This means that the change in the rate would be linked to other unrelated determinants. Even more, FGT1 values indicate an increase from $34.89 \%$ to $38.94 \%$. Thus, the estimated rate during the second period at $34.89 \%$ will be caught only during the third period, the simulation then estimating $34.80 \%$.

As for the depth of poverty, which measures the distance separating members of a population to the poverty line, it goes from $10.14 \%$ to $16.27 \%$ between 2016 and 2023. So, an increase of 6.13 percentage points is recorded. This increase is attributed to $0.76 \%$ growth effect and $5.53 \%$ redistributive effect against a residual effect of $-0.16 \%$. This means that the poor are moving further and further away from the poverty line due mainly to a poor redistribution of the wealth created, their income remaining unchanged and marginally as a result of the growth generated. This observation does not escape the severity of poverty (FGT2) which is raised to more than $75 \%$ by the redistributive component and to $0.44 \%$ by the growth component against a residual effect of $-5.64 \%$.

Another lesson is that the impact of the EPA is the lowest in the period 2033-2040, regardless of the FGT index. In addition, it decreases with the FGT index (FGT0 to FGT2). This shows that the EPA has a negative impact because it increases poverty indicators, but it does not amplify as much the distance between the poor and the poverty line (since those who are not poor are a zero distance from this threshold) that poverty in itself is increasing at the national level. This is increasing with the severity of poverty, which suffers very little from this negative impact.

Depending on the place of residence, there is a general finding that the EPA also leads to an increase in poverty whether one is in urban or rural areas. This is in fact an observation made at the national level. However, poverty is higher in rural than in urban areas. But the impact is greater on the incidence of poverty in rural than in urban areas. In other words, the poverty rate will increase more in rural than in urban areas. On the other hand, the depth and severity of poverty will grow faster in urban areas than in rural areas. One could therefore be surprise about the factors that caused these changes in urban and rural areas. 
In this regard, the determinants of poverty in Cameroon are almost the same in rural as in urban areas. For example, ECAM 4 in its report on trends, profile and determinants of poverty in Cameroon between 2001 and 2004 shows that the level of education, trade, employment, access to credit, land used are some determinants of poverty common to both areas. On the other hand, factors such as employment, the practice of industrial and export agriculture, livestock farming, fishing, forestry, migration, and administrative services are determinants of poverty in urban areas only. Similarly, access to financial services and telecommunications and the practice of small ruminant farming are crucial only in rural areas.

All of these results show, as Fombon (2017) has pointed out, that the poor will receive almost no beneficial effect from growth effects. Which situation will get worse with the EPA.

In terms of inequality, we measure them by the second-order GINI index, which offers a comparison with the Herfindahl index (Chameni, 2005). Let's note from the onset that the EPA is increasing marginal income inequality in Cameroon, regardless of the place of residence. Nevertheless, this impact vanishes during the third period. We also note that inequalities are more observed in urban areas where the value of the Gini index is the highest. Rural areas, however, have low inequalities. In addition, it is the only environment where one can observe a reduction of inequalities, intervened during the period 2016-2023. In fact, the Gini index has risen from 0.3819 to 0.3813 , a reduction of 0.06 percentage points in inequality. This means that the application of the EPA will not allow farmers who are predominant to benefit from it. On the contrary, it will help to reduce the income of a few previously affluent households for the benefit of the less affluent. This is a consequence of the aggravation of poverty indicated previously.

Table 12. Impact poverty and inequality.

\begin{tabular}{|c|c|c|c|c|c|c|}
\hline \multirow{2}{*}{ Indexes* } & \multicolumn{3}{|l|}{ Basis value } & \multicolumn{3}{|c|}{ Value after simulation } \\
\hline & $2016-2023$ & $2024-2032$ & $2033-2040$ & $2016-2023$ & $2024-2032$ & $2033-2040$ \\
\hline \multicolumn{7}{|c|}{ At the national level } \\
\hline FGT0 & 36.35 & 34.89 & 32.33 & 39.73 & 38.94 & 34.80 \\
\hline FGT1 & 13.52 & 12.75 & 11.52 & 17.59 & 33.26 & 12.74 \\
\hline FGT2 & 6.56 & 6.44 & 5.75 & 42.44 & 14.47 & 6.43 \\
\hline GINI & 0.4319 & 0.4319 & 0.4319 & 0.4694 & 0.6442 & 0.4319 \\
\hline \multicolumn{7}{|c|}{ In urban area } \\
\hline FGT0 & 27.75 & 26.49 & 24.39 & 30.83 & 30.57 & 26.47 \\
\hline FGT1 & 10.14 & 9.55 & 8.60 & 16.27 & 49.17 & 9.54 \\
\hline FGT2 & 5.08 & 4.74 & 4.21 & 74.94 & 31.65 & 4.73 \\
\hline GINI & 0.4371 & 0.4371 & 0.4371 & 0.4938 & 0.7764 & 0.4371 \\
\hline \multicolumn{7}{|c|}{ In rural area } \\
\hline FGT0 & 43.86 & 42.22 & 39.25 & 47.49 & 46.24 & 42.06 \\
\hline FGT1 & 16.47 & 15.54 & 14.06 & 18.74 & 19.39 & 15.53 \\
\hline FGT2 & 8.46 & 7.92 & 7.09 & 14.10 & 1.38 & 7.91 \\
\hline GINI & 0.3819 & 0.3818 & 0.3818 & 0.3913 & 0.4283 & 0.3818 \\
\hline
\end{tabular}

*poverty indexes are given in percentage

Table 13. Poverty index decomposition at the national level

\begin{tabular}{lllllll}
\hline \multirow{1}{*}{ Indices $^{*}$} & \multicolumn{2}{c}{ Reference period $=1$} & \multicolumn{3}{l}{ Reference period $=2$} \\
\cline { 2 - 7 } & $2016-2023$ & $2024-2032$ & $2033-2040$ & $2016-2023$ & $2024-2032$ & $2033-2040$ \\
\hline Growth & 0.015388 & -0.264895 & 0.020835 & 0.014337 & -0.973982 & 0.020835 \\
Redistribution & 0.016461 & 0.522128 & 0.000000 & 0.015409 & -0.186957 & 0.000000 \\
Residue & -0.001052 & -0.709086 & 0.000000 & 0.001052 & 0.709086 & 0.000000 \\
Total effect & 0.030797 & -0.451853 & 0.020835 & 0.030798 & -0.451853 & 0.020835 \\
& & & FGT1 & & & \\
Growth & 0.007596 & -0.095485 & 0.009343 & 0.005988 & -28.919554 & 0.009343 \\
Redistribution & 0.055323 & -0.417373 & -0.0000002 & 0.053725 & -29.241441 & 0.0000001 \\
Residue & -0.001607 & -28.824069 & 0.00000004 & 0.001607 & 28.824069 & -0.0000004 \\
Total effect & 0.061312 & 29.336927 & 0.0093428 & 0.061320 & -29.336926 & 0.0093431 \\
& & & & & \\
Growth & 0.004415 & -0.047380 & 0.005199 & -0.052025 & -4991.5525 & 0.005199 \\
Redistribution & 0.750648 & -6.769252 & -0.0000001 & 0.694208 & -4998.2744 & 0.00000001 \\
Residue & -0.056440 & -4991.5052 & 0.00000001 & 0.056441 & 4991.5051 & -0.0000001 \\
Total effect & 0.698623 & -4998.3218 & 0.005199 & 0.698624 & -4991.5525 & 0.005199 \\
\hline
\end{tabular}

*these indexes are those of Datt et Ravallion (1992) 


\subsubsection{Impact on well-being}

As in Table 14 below, the Cameroonian EPA leads to an improvement in the well-being of both salaried and capitalist households. Well-being is measured by the equivalent variation approach (see Decaluwé et al., 2001 page 271). Over the years, the welfare of households improves with a much more accentuated character on the side of salaried households. In relation to the latter, the level of income necessary to ensure the indirect utility induced by the EPA will have increased by CFAF 81.35 billion during the period 2016-2023; CFAF 120.84 billion in the period 2024-2032; and CFAF 290.86 billion during the period 2033-2040. This means, for example for the first period that the income of salaried households would have to be reduced by CFAF 81.35 billion to maintain their level of utility if the EPA had not been signed. As for the capitalist households, the improvement of the well-being is estimated respectively at CFAF 7.32; 10.35; and 26.52 billion over the three periods. These results are valid both theoretically and empirically. They agree with the results of the work of Adamu (2013), Onogwu \& Arsene (2013), Bouët et al. (2017) for the case of Côte d'Ivoire and Burkina Faso.

Table 14. Impact on well-being

\begin{tabular}{llll}
\hline Households & Equivalent variation (value in CFAF billion) & \\
\cline { 2 - 4 } & $2016-2023$ & $2024-2032$ & $2033-2040$ \\
\hline Salaried households & 81.35 & 120.84 & 290.45 \\
Capitalist households & 7.32 & 10.35 & 26.52 \\
\hline
\end{tabular}

Source: Authors from GAMS software

\subsection{Results of the Robustness of the Results}

We plan here to check the sensitivity of our results following a modification of the value of a given parameter. Thus, the $10 \%$ reduction in the constant transformation elasticity that is according to Hosoe et al. (2010) a relevant parameter in the robustness analysis makes it possible to obtain the results summarized in the following Tables 16 and 17. For simplification, these results relate only to the first period 2016-2023, but it should be mentioned that the trend observed over this period is maintained over the other two periods. In commercial terms, this result shows that imports as well as exports retain their sign, even if the new values have some deviations.

For example, agricultural imports, which increased by $0.91 \%$ (see Table 15 ), now increase by $0.14 \%$. So, 0.77 percentage point downward shift occurred. On the other hand, we observe that agricultural exports, which were down $0.65 \%$, are now down by $0.83 \%$. A rather small change is recorded at this level. In terms of prices, the market price, for example outside the agricultural sector, is continuing to trend. Overall customs duties, with the exception of the services sector, have the same trend. The trend is maintained for the well-being indicated in Table 17. These illustrations contribute to validate the hypothesis of the sensitivity of our results to the parameters of the model.

Table 15 . Impact before a $10 \%$ reduction of constant elasticity of transformation (value in \%)

\begin{tabular}{llll}
\hline & Agriculture & Industry & Services \\
\hline Imports & 0.91 & -0.24 & 1.72 \\
Exports & -0.65 & -0.24 & -0.62 \\
Demande for product tr & -1.02 & -0.28 & -0.11 \\
Intermediate demand of branches & -0.66 & -0.38 & -0.19 \\
Market price of product tr & -1.45 & -1.46 & -0.11 \\
Price for exportable Product & -16.24 & 7.01 \\
Price of products sold by producers in the local market & 0.08 & 1.70 & 0.01 \\
Local market price for imported product tr & 21.95 & 1.07 & -297.00 \\
Producer's price of product tr & 0.13 & -12.06 & -0.10 \\
Value added price & 0.20 & 0.29 \\
Composite demand & -0.04 & -3.00 & 0.00 \\
Indirect tax & -2.32 & 0.02 & -0.02 \\
Total customs revenue & -1.31 & 0.68 & -0.02 \\
Customs revenue on the rest of the world & 0.37 & -1.00 & 0.43 \\
\hline
\end{tabular}

Source: Authors from GAMS software 
Table 16. Impact after a 10\% reduction of the constant elasticity of transformation (value in \%).

\begin{tabular}{llll}
\hline & Agriculture & Industry & Services \\
\hline Imports & 0.14 & -0.33 & 16.57 \\
Exports & -0.83 & -0.51 & -0.65 \\
Demand for product tr & 0.22 & 0.16 & -0.19 \\
Intermediate demand of branches & 0.12 & -0.16 & -0.03 \\
Market price of product tr & 0.83 & -2.85 & -0.02 \\
Price for exportable Product & -1.89 & -3.01 & 23.26 \\
Price of products sold by producers in the local market & 0.05 & 0.19 & 0.32 \\
Local market price for imported product tr & 43.72 & 45.11 & -289.96 \\
Producer's price of product tr & -0.05 & -4.95 & -0.17 \\
Value added price & -0.07 & 0.27 & 0.14 \\
Composite demand & -0.06 & 0.03 & -0.01 \\
Indirect tax & 1.33 & 0.37 & 0.15 \\
Total customs revenue & -1.28 & -1.17 & 0.88 \\
Customs revenue on the rest of the world & 0.87 & -0.74 & 1.41 \\
\hline
\end{tabular}

Source: Authors from GAMS software

Table 17. Impact on households' well-being

\begin{tabular}{llll}
\hline Households & Equivalent variation (value in CFAF billion) & \\
\cline { 2 - 4 } & $2016-2023$ & $2024-2032$ & $2033-2040$ \\
\hline Salaried households & 204.39 & 344.43 & 329.91 \\
Capitalists households & 17.08 & 28.34 & 27.08 \\
\hline
\end{tabular}

Source: Authors from GAMS software

\section{Conclusion}

In this study we analyzed the microeconomic impacts of the Cameroon-EU bilateral EPA through a computable general equilibrium microsimulation model. To our knowledge this study appears to be almost the first to investigate the microsimulation impacts of the Cameroon's EPA as the letter has been implemented recently in 2016. Furthermore, our SAM is updated since it concerns the year 2016 and the model is calibrated in a dynamic framework. As results, it appears that the agreement undermines and even exacerbates poverty reduction efforts through incidence indices (FGT0), depth (FGT1) and severity of poverty (FGT2). This impact is increasing over the years from 2016 to 2040 and is more pronounced in rural than in urban areas. Even though this founding is not in line with former works on EPAs, this can be due to a number of factors regardless to the poverty determinants in Cameroon: the trade deficit, access to credit, the practice of industrial and export agriculture. An explanation for the latter can be the reduction of the production in that branch as a macroeconomic impact. In line with inequality results, the dismantling of customs barriers has led to an increase in inequalities ranging from 0.43 to 0.46 during the period 2016-2023. This means that the richest households will become wealthier at the expense of poor households. However, the impact is vanished at the third period 2033-2040. On the other hand, urban households suffer the greatest impact. In view with these trends, the continuation of the application of the agreement leaves much fear as a crowding out effect which can jeopardize the remarkable efforts undertaken by the government in its program of emergency.

\section{Acknowledgements}

The authors would like to thank especially Mouafo Paul for his insightful help, comments and discussion.

\section{References}

Annabi, N., Cissé, F., Cocburn, J., \& Decaluwé, B. (2006). Libéralisation commerciale, croissance et pauvreté au Sénégal: Une analyse à l'aide d'un MEGC microsimulé dynamique. Politiques économiques et pauvreté (PEP), CRDI.

Ayoki, M. (2013). Computable General Equlibrium Micro Simulation Analysis of the Impact of Trade Policy on Poverty in Uganda. Institute of Policy Research and Analysis. Retrieved from https://mpra.ub.uni-muenchen.de/78876/

Bernal, R. (2013). Globalization, Trade, and Economic Development The CARIFORUM-EU Economic Partnership Agreement. palgrave macmillan, Ltd; Chennai, India.

Bouët, A., Dienesch, E., \& Fall, C. (2013). What are the expected effects of trade policies on Poverty in Senegal? A CGE Micro-Macro Analysis. GTAP 16th Annual Conference on Global Economic Analysis, Shanghai, (June pp.12-14), 2013. https://doi.org/10.1080/09638199.2017.1337803 
Bouët, A., Laborde, D., \& Traoré, F. (2017). The European Union-West Africa Economic Partnership Agreement: Small impact and new questions. The Journal of International Trade \& Economic Development.

Bourguignon, F., \& Spadaro, A. (2006). Microsimulation as a Tool for Evaluating Redistribution Policies. Working Paper Series: Society for the study of Economic Inequality ECINEQ 2006-20 January 2006 www.ecineq.org.

Bourguignon, F., Robilliard, A., \& Robinson, S. (2003b). Representative versus real households in the macro-economic modelling of inequality. DT/2003/10, DIAL/Unité de recherche CIPRE.

Boysen, O., \& Mathews, A. (2009). The Economic Partnership Agreement between Uganda and the UE: Trade and poverty impacts. Institue for International Intergration Studies. Discussion paper $\mathrm{N}^{\circ} 307$ / novembre 2009. https://doi.org/10.2139/ssrn.1282191

Boysen, O., \& Matthews, A. (2016). Will Economic Partnership Agreements increase poverty? The case of Uganda. Review of Development Economics. https://doi.org/10.1111/rode.12272

Carim, X. (2017). South Africa, the EU, and the SADC Group Economic Partnership Agreement: Through the Negotiating Lens. A. Montoute, K. Virk (eds.), The ACP Group and the EU Development Partnership, (pp.161-179). https://doi.org/10.1007/978-3-319-45492-4_7

Chameni, N. (2005). A three components subgroup decomposition of the Hirschman-Herfindahl index and household's income inequalities in Cameroon. Applied Economics Letters, 12(15), 941-947. https://doi.org/10.1080/13504850500377959

Cockburn, J. (2001). Trade Laberalisation and Poverty in Nepal: A Computable General Equilibrium Micro simulation Analysis. Centre for the Study of African Economies and Nuffield College, Oxford University.

Cororaton, B. (2004). Philippine-Japan Bilateral Agreements: Analysis of Possible Effects on Unemployment, Distribution and Poverty in the Philippines Using CGE-Microsimulation Approach. Discussion Paper Series, No. 2004-01 Philippine Institute for Development Studies (PIDS), Philippines Makati City.

Cororaton, B. (2016). Potential effects of the Regional Comprehensive Economic Partnership on the Philippine economy. PIDS discussion paper series $N^{\circ}$. 2016-30, Philippine Institute for Development Studies (PIDS), Philippines Makati City.

Dagdeviran, H., Van der hoerven, R., \& Weeks, J. (2000). Redistribution matters: growth for poverty reduction. Department of Economics Working Paper Series No. 99, School of Oriental and African Studies (SOAS), University of London.

Decaluwé, B., Martens, A., \& Savard, L. (2001). La politique économique du développement et les modèles d'équilibre général calculable. Les Presses de l'Université de Montréal.

Dodd, S., \& Cattaneo, N. (2006). Theoretical approaches to the analysis of trade and poverty and a review of related literature on South Africa. United State Agency and International Development, University of Cap Town.

Dollar, D. (2001). Globalization, inequality and poverty since 1980. World Bank, Washington DC.

Elgstrom, O., \& Larsén, M. (2010). Free to trade? Commission autonomy in the Economic Partnership Agreement negotiations. Journal of European Public Policy, 17(2), 205-223. https://doi.org/10.1080/13501760903561674

Emini, C., Zogo, V., Feunou, D., \& Tadjuidj, M. (2006). Décomposition des effets des politiques économiques sur l'évolution de la pauvreté au Cameroun : Une analyse en équilibre général micro-simulé avecdouble-calibration. Réseau Politiques Economiques et Pauvreté: Rapport Final.

Fako, B., Ndem, F., \& chakote, R. (2005). Pauvreté et inégalités des conditions de vire au Cameroun: une approche micro multidimensionnelle. PEP research network general meeting, (june pp.13-17).

Fambon, S. (2017). Pro Poor Growth in Cameroon. Statistika, 97(2).

Fofana, I. (2007). Elaborer une Matrice de Comptabilité Sociale Pour l'Analyse d'Impacts des Chocs et Politiques Macroéconomiques. Centre Interuniversitaire sur le Risque, les Politiques Economiques et l'Emploi (CIRPEE) Université Laval, Québec, Canada.

Foster, J., Greer, J., \& Thorbecke, E. (1984). A class of decomposable poverty measures. Econometrica, 52(3), $761-766$. https://doi.org/10.2307/1913475

Frankel, J., \& Romer, D. (1999). Does trade cause growth? American Economic Review, 89(3), $379-399$. https://doi.org/10.1257/aer.89.3.379

Herault, N. (2007). Trade Liberalisation, Poverty and Inequality in South Africa: A Computable General Equilibrium Microsimulation Analysis. The Economic Record, 83(262), 317-328. 
https://doi.org/10.1111/j.1475-4932.2007.00417.x

Hosoe, N., Gasawa, K., \& Hashimoto, H. (2010). Textbook of computable general equilibrium modelling. Hampshire: Palgrave Macmillan. https://doi.org/10.1057/9780230281653

INS. (2017). les comptes nationaux trimestriels (2ème trimestre 2017). Une Publication du Département des Synthèses Economiques; $\mathrm{N}^{\circ} 021$ : Octobre 2017; www.statistics-cameroon.org.

Jones, R. (1971). A three-factor model in theory, trade and history. In Bhagwati, J; Jones, R; Mundell, R.A. and Vanek, J. (eds), Trade, Balance of Payments and Growth: Papers in International Economics in Honor of Charles P. Kindleberger, North-Holland, Amsterdam: 3(21).

Kaldor, N. (1939). Speculation and Economic Stability. The Review of Economic Studies, 7(1), 1-27. https://doi.org/10.2307/2967593

Kiely, R. (2004). The World Bank and "global poverty reduction": good policies or bad data? . Journal of Contemporary Asia, 34(1), 3-20. https://doi.org/10.1080/00472330480000271

Kuruk, P. (2012). Investment Issues In The West Africa-European Union Economic Partnership Agreement Negotiations: Is A Harmonised Regional Investment Framework The Answer? African Journal Of International And Comparative Law, 20(3), 448-470. https://doi.org/10.3366/ajicl.2012.0045

Obeng, C. (2015). Impact of Trade Libaralisation on Poverty: a dynamic computable general equilibrium and microsimulation analysis for Ghana. International Journal of development, 2(1).

Omgba, L., \& Djiofack, C. (2014). Oil and Developement in Cameroon: A critical appraisal of the permanent income hypothesis. Energy Policy, 39(11). https://doi.org/10.1016/j.enpol.2011.08.041

Onogwu, G. (2013). Trade, revenue and welfare effects under an economic partnership agreement between burkina faso and the european union. Russian Journal of Agricultural and Socio-Economic Sciences, 2(14). https://doi.org/10.18551/rjoas.2013-02.05

Rodriguez, F., \& Rodrik, D. (1999). Trade policy and economic growth: a skeptic's guide to the cross-national evidence. NBER Working Paper No.w7081 (revised version, May 2000). https://doi.org/10.3386/w7081

Samuelson, P. (1947). Foundations of Economic Analysis. Harvard University Press.

Samuelson, P. (1971). Ohlin was right. Swedish Journal of Economics, 73, 365-384. https://doi.org/10.2307/3439219

Shoven, J. (1988). Government policy towards industry in the United States and Japan. Cambridge University Press. https://doi.org/10.1017/CBO9780511572111

Spadaro, A. (2007). Microsimulation as a tool for the evaluation of public policies method and applications. (ed). Bilbao : Fundación BBVA, 2007. pp.357.

Stolper, W., \& Samuelson, P. (1941). Protection and real wages. Review of Economic Studies, 9, 58-73. https://doi.org/10.2307/2967638

Viroleau, F. (2015). The Evolution of Gender Wage Inequality in Senegal Following the Economic Partnerhip Agreements. Economix; Document de travail; working paper 2015-10.

Weinhardt, C., \& Moerland, A. (2017). (Mis)Perceptions in Two- and Three-Level Games: Detachment in Economic Partnership Agreement Negotiations. Journal of Common Market Studies, 1-18. https://doi.org/10.1111/jcms. 12642

Winters, L. (2000a). Trade and poverty: is there a connection? In Ben-David, D; Nordstrom, H. and Winters, L; Trade, Income Disparity and Poverty, World Trade Organisation (WTO) Special Studies No. 5, WTO, Geneva, 43-69.

\section{Copyrights}

Copyright for this article is retained by the author(s), with first publication rights granted to the journal.

This is an open-access article distributed under the terms and conditions of the Creative Commons Attribution license which permits unrestricted use, distribution, and reproduction in any medium, provided the original work is properly cited. 